OPEN ACCESS

Edited by:

Juliet Willetts,

University of Technology Sydney,

Australia

Reviewed by:

Guy Norman,

WSUP, United Kingdom

Vhahangwele Masindi,

Council for Scientific and Industrial

Research (CSIR), South Africa

Mark John Ellery,

Consultant, Perth, Australia

Catarina Fonseca,

IRC International Water and Sanitation Centre, Netherlands

*Correspondence: Alyse Schrecongost Alyse.schrecongost@ gatesfoundation.org

Specialty section:

This article was submitted to Water and Wastewater Management, a section of the journal

Frontiers in Environmental Science

Received: 23 August 2019

Accepted: 11 February 2020

Published: 28 February 2020

Citation:

Schrecongost A, Pedi D, Rosenboom JW, Shrestha R and Ban R (2020) Citywide Inclusive Sanitation: A Public Service Approach for Reaching the Urban Sanitation SDGs. Front. Environ. Sci. 8:19. doi: 10.3389/fenvs.2020.00019

\section{Citywide Inclusive Sanitation: A Public Service Approach for Reaching the Urban Sanitation SDGs}

\author{
Alyse Schrecongost*, Danielle Pedi, Jan Willem Rosenboom, Roshan Shrestha and \\ Radu Ban
}

Bill \& Melinda Gates Foundation, Seattle, WA, United States

This policy brief sets out key concepts, principles and practical implications for the citywide inclusive sanitation (CWIS) approach. Rapid urbanization, aging infrastructure, and climate change are exacerbating a sanitation crisis. The focus of most urban sanitation interventions remains incremental expansion of centralized sewer infrastructure; little attention is paid to reaching the poor, long-term service provision, financial viability, or the public system functions required to achieve those outcomes. Meeting SDG targets requires a radical rethink of the urban sanitation sub-sector. CWIS offers this. This paper presents a public services framework, set out by the Gates Foundation, for pursuing equitable, safe and sustained service outcomes, at city scale. It reviews the genesis and evolution of the CWIS framework and shares key principles and policy implications.

Keywords: citywide inclusive sanitation, SDG, equity, urban sanitation, urban basic service

\section{INTRODUCTION: THE URBAN SANITATION CRISIS}

By 2018, 55\% of the world lived in cities (United Nations [UN], 2014; World Bank, 2019); rapid urban growth will continue to occur in LDCs, where urban populations have already doubled in the last 15 years UNICEF (2019b). Based on the sustainable development goals, urban sanitation services should yield safe, equitable, and sustained sanitation outcomes for everyone, prioritizing vulnerable groups. Urban sanitation service expansion, however, has been slow and uneven (UNICEF, 2019b). Although most countries have increased urban sanitation coverage between 2000 and 2017, and many have shrunk the access gap between the richest and the poorest, in 36 low-income countries urban coverage is either decreasing (8 countries), becoming more unequal ( 22 countries), or both ( 6 countries). Over 622 million urban residents lack basic sanitation globally, and 2.2 billion urban residents, or $29 \%$ of the entire global population, do not use safely managed sanitation services (UNICEF, 2019b).

On-site hardware, such as pits and septic tanks, is the predominant containment used in urban Sub-Saharan Africa and South- and Central Asia, UNICEF (2019b). Yet, the focus of ministries, urban sanitation authorities, master plans, and development finance covering $60 \%$ of the population remains on incremental expansion of centralized sewers benefitting small, nonpoor segments of urban populations. Little attention is paid to reaching the poor, non-sewered populations, long-term service provision, or prevailing climate and urban conditions.

Public investments are too few (UN-Water GLAAS, 2017), and consistently struggle to yield sustainable, pro-poor results. For example, a World Bank evaluation of US $\$ 30.3$ billion of 
investments in water supply and sanitation between 2007 and 2016 found that over $40 \%$ of projects faced significant or high outcome risks, mainly due to lack of financial viability or institutional accountability; only $4 \%$ of projects declared financial viability as an explicit objective (The World Bank Group, 2017). Similarly, an evaluation of the Asian Development Bank's urban water and sanitation portfolio over a similar timeframe found that only 7 out of 63 evaluated projects included on-site components (in addition to centralized systems) and that the poor were given low priority in most projects (ADB, 2018).

The fact that the prevailing approaches struggle to provide inclusive and sustainable services is known among experienced professionals, but discussions tend to focus on insufficient finance. Systematic evidence and analysis of challenges are sparse and tend to be documented in gray literature, including fragmented, project-, and country specific reports. The mismatch between the urban sanitation needs in low-income countries and the prevailing interventions reflects how the sector including WASH engineering education - have been shaped by historical factors and norms more than by data, transparency, and clear service delivery goals. This is exacerbated by neglected investment in service authorities' data collection systems. The sector tends to invest in expensive project estimates in the absence of data systems, to aggregate water and sanitation estimates, and to neglect collection of basic data on sanitary conditions in low-income areas and informal settlements.

Efforts to address the specific needs of those with on onsite containment by formalizing fecal sludge management (FSM) services have made substantial gains in the past 10 years (Strande and Ronteltap, 2014; Blackett and Hawkins, 2017), but these approaches are largely supported outside of mainstream or public planning and practice, thereby limiting their reach and impact (see table on page 5 for a comparison among the approaches). Framing the urban sanitation challenge from a technology lens (e.g., "sewered" vs. "non-sewered") establishes a false dichotomy. It retains focus on hardware inputs rather than how a city's service delivery system functions and the resulting outcomes. The latter requires planning and investment in incremental hardware and service improvements across diverse contexts within cities (The Bill and Melinda Gates Foundation [BMGF], 2016); it also requires planning and investment in the infrastructure of public service delivery, accountability and financing systems, including things like public information, monitoring, and grievance redressal mechanisms. This latter approach calls into focus the limitations of existing technologies and products to meet the needs of many urban contexts, and it illuminates the missing source of market demand for innovation.

\section{TOWARD A NEW FRAMEWORK: DEFINING CITYWIDE INCLUSIVE SANITATION}

Recognizing the urban sanitation crisis, its disproportionate burden on the urban poor, and the limited progress of prevailing approaches, a group of organizations met at the 2015 Hanoi FSM3 Conference to discuss the need for an urban "sanitation revolution ${ }^{1}$." The sector had failed to achieve the toilet-focused MDG targets for sanitation, but was preparing to commit to even more ambitious SDG targets for "safely managed" sanitation across the service chain. The conversation reflected lessons from a portfolio of DFID-BMGF city grants supporting outcome contracting. Weak or missing sanitation authority mandates and lack of accountability for services constrained efforts to formalize and improve them (Aquaconsult, 2018). A larger multi-disciplinary group of practitioners, development partners, researchers, and others convened in Atlanta in 2016 to identify ways to accelerate progress in providing sanitation services for the urban poor.

The Atlanta workshop resulted in the citywide inclusive sanitation (CWIS) concept and "Call to Action" (BMGF, 2016) signed by over 70 organizations and individuals. CWIS was characterized as:

Everyone benefits from adequate sanitation service delivery outcomes; human waste is safely managed along the whole sanitation service chain; effective resource recovery and re-use are considered; a diversity of technical solutions is embraced for adaptive, mixed and incremental approaches; and onsite and sewerage solutions are combined, in either centralized or decentralized systems, to better respond to the realities found in developing country cities.

The call to action highlighted the need for long-term planning, technical innovation, institutional reforms, and financial mobilization, as well as political will and technical and managerial leadership for systems change (BMGF, 2016). It outlined four CWIS building blocks: (1) Prioritization of the right of all to sanitation, with inclusive strategies reaching informal settlements and vulnerable populations; (2) Delivery of "safe management" along the entire sanitation service chain by focusing on service outcomes rather than technologies, and by embracing innovation and incrementalism; (3) Recognition of sanitation's contribution to a thriving urban economy by integrating sanitation into urban planning, reforming regulatory policies, and embracing resource recovery and reuse; and (4) Commitment to work in partnership across sectors and stakeholders to make progress through clear institutions with accountability, embedding sanitation within urban governance systems.

After a series of regional consultative workshops with ministerial, municipal and utility leaders, economic regulators, engineering firms, and development partners from over 40 countries, the CWIS building blocks and objectives (Gambrill et al., 2016), were refined into an SDG-aligned definition:

A public service approach to planning and implementing urban sanitation systems to achieve outcomes summarized by SDG 6: safe, adequate, equitable, and sustainable sanitation for everyone in an urban area, paying special attention to the needs of the poor, the marginalized, and of women and girls, a comprehensive set of seven CWIS principles (Figure 1), and service framework (Figure 2).

\footnotetext{
${ }^{1}$ Initial meeting included representatives from the Bill \& Melinda Gates Foundation, Emory University, Plan International, the University of Leeds, WaterAid, and the World Bank.
} 


\section{SEVEN PRINCIPLES FOR CITYWIDE INCLUSIVE SANITATION}

1. EVERYONE IN AN URBAN AREA, INCLUDING THE URBAN POOR, BENEFITS FROM EQUITABLE SAFE SANITATION SERVICES

- Everyone. Legal mandate is based on urban planning principles, without restrictions based on land tenure, hardware type, or local political boundaries; Transient, permanent, worker, and downstream communities' needs are met;

- Equitable. Prices reflect service levels, affordability; availability and legitimacy of public finance is decoupled from hardware type or on-plot/off-plot siting; subsidized finance prioritized for the poorest;

- Safe. Users' waste is safely managed and all communities are free of others' waste.

2. GENDER AND SOCIAL EQUITY ARE DESIGNED INTO PLANNING, MANAGEMENT, MONITORING

- Those who are marginalized, without formal land tenure or access to sewers, women, and children are intentionally engaged in decision making systems;

- Users' and workers' needs, values, constraints, and voices are understood and incorporated into hiring, service delivery planning, and service delivery;

- Workers' health and rights are protected by occupational health and safety measures.

\section{HUMAN WASTE IS SAFELY MANAGED ALONG SANITATION SERVICE CHAIN, STARTING WiTH} CONTAINMENT

- Infrastructure and service delivery systems protect workers, households, communities at all stages from containment through disposal/reuse;

- Containment and connections are managed to protect groundwater and environmental health;

- Hardware investments and service models position resource recovery as a tool to incentivize safe waste management.

4. Authorities operate With a CLEAR, inClusive mandate, PERFormance targets, RESOURCES, AND ACCOUNTABILITY

- Mandate for urban sanitation is clearly defined, assigned to service authorit(ies) without overlap, explicitly prioritizes serving the poor, and is reflected in the authority's key performance indicators;

- Processes exist to establish performance levels and set progressive targets for achieving them;

- Service authority performance targets are monitored and tied to regulatory penalties and incentives;

- Financing and revenue opportunities are designed to sufficiently support implementation of mandates.

5. AUTHORITIES DEPLOY A RANGE OF FUNDING, BUSINESS, AND HARDWARE APPROACHESSEWERED / NON-SEWERED-TO MEET GOALS

- Sanitation service mandates are technology agnostic; planning and investments support incremental and integrated systems that prioritize resources for achieving safety, equity, and sustainability;

- Service authorities may deploy a range of business models to reach different customer segments within a city efficiently and equitably.

6. COMPREHENSIVE LONG-TERM PLANNING FOSTERS DEMAND FOR INNOVATION AND IS INFORMED BY ANALYSIS OF NEEDS/RESOURCES

- Investment and finance decisions are based on activity-based accounting of costs and revenues and inclusive performance targets;

- Investment and planning are informed by climate change, water, and energy constraints;

- Performance incentives foster service authority capacity, responsiveness, and innovation;

- Investment planning and prioritization processes are documented, transparent, engage relevant stakeholders;

- Processes are coordinated with those of other urban investments and services, e.g. neighborhood upgrades, water services, storm water and greywater management, roads.

7. POLITICAL WILL AND ACCOUNTABILITY SYSTEMS INCENTIVIZE SERVICE IMPROVEMENTS IN PLANNING, CAPACITY, AND LEADERSHIP

- Commitment to safe inclusive urban sanitation is demonstrated at multiple levels of government;

- Budget allocations and expenditures are transparent and set based on equity and performance accountability;

- Accountability systems such as performance regulators are designed to be autonomous and independent and to empower marginalized voices;

- Service authorities have support from politicians for effective institutional reforms, like tariff-setting and enforcement.

FIGURE 1 | Seven principles for citywide inclusive sanitation. 


\begin{tabular}{|c|c|c|c|}
\hline 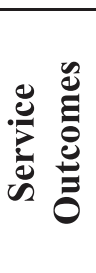 & \begin{tabular}{l}
\multicolumn{1}{c}{ EQUITY } \\
'Fairness' in distribution and \\
prioritization of services, \\
service quality, service \\
prices, and use of public \\
finance/subsidies
\end{tabular} & $\begin{array}{l}\text { SAFETY } \\
\text { All human waste is managed to } \\
\text { protect public goods* for } \\
\text { customers, workers and all } \\
\text { communities }\end{array}$ & $\begin{array}{l}\quad \text { SUSTAINABLITY } \\
\text { Management of revenues and } \\
\text { resources--financial, labor, } \\
\text { energy, water--sustain } \\
\text { performance }\end{array}$ \\
\hline \multirow{2}{*}{ 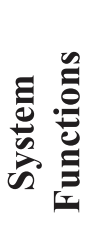 } & & ACCOUNTABILITY & $\begin{array}{c}\text { RESOURCE PLANNING \& } \\
\text { MANAGEMENT }\end{array}$ \\
\hline & $\begin{array}{l}\text { Authority or authorities } \\
\text { execute a clear mandate to } \\
\text { ensure inclusive, safe } \\
\text { sanitation services }\end{array}$ & $\begin{array}{l}\text { Performance is monitored and } \\
\text { managed with transparency, } \\
\text { data, incentives and penalties }\end{array}$ & $\begin{array}{l}\text { Resources are managed to support } \\
\text { implementation of mandate and } \\
\text { achieve goals across time / space }\end{array}$ \\
\hline
\end{tabular}

FIGURE 2 | CWIS service framework. *Public Goods are the elements of sanitation service delivery system characterized by market failures -technically, non-excludability and non-rivalry. Practically, they are the elements of sanitation service that are outside of individuals' direct private interests and can include safe on-site containment, network connections, transporting waste to safe disposal, and other activities required for long-term protection of water, land and public health along the value chain.

Citywide inclusive sanitation is explicitly agnostic about technology choice. Clear service outcomes - for all residents, in sewered and non-sewered areas - and system feasibility considerations (e.g., financial, environmental, political, organizational capacity, cultural, and other factors) inform system design and technology choice. CWIS is based on the fundamental understanding that urban human waste management is characterized by inherent market failures, and therefore must be organized as a public service - including ensuring safe containment - to achieve public interest components of sanitation (i.e., safety and inclusivity). This requires government engagement in market structuring; it does not preclude or diminish the role of the private sector. For service authorities to achieve the outcomes embedded within their legal mandates, they must ensure services are well executed. This expands opportunities for private sector participation by creating market incentives for investment and innovation.

Figure 2 presents a CWIS service framework which captures a simplified set of core outcomes and required functions of a public service delivery system for sanitation, relevant across diverse city contexts. Core outcomes of a system are equity, safety and sustainability, for everyone in an urban area, not just those in sewered areas. To achieve these outcomes, a system must demonstrate three functions: there must be a responsible authority(ies) executing a clear, legal mandate for inclusive urban service delivery; the legal authority(ies) must be accountable for performance against mandated responsibilities; and processes for planning and managing resources - financing, assets, people across time and place must be transparently tied to mandated priorities and performance accountability.

The CWIS service framework identifies core outcomes and functions for public service delivery systems. The specifics of how outcomes are defined and how functions are institutionalized and executed will vary by country and city. Sanitation authorities need to consider an evolving range of diverse technologies and business models to generate service improvements over time, including delegation of service provision to the private sector when appropriate. Likewise, a range of models and tools are needed for meaningful accountability and resource management in different contexts, including but not limited to economic regulators. Irrespective of context, any well-functioning service system relies on robust, institutionalized performance indicators and effective monitoring systems to inform decisions.

The core elements of the CWIS service framework are not new; they reflect tenets of public service systems (Klein, 1996; Komives, 1999; Galli et al., 2014). In the urban water subsector, priority outcomes are defined and monitored using performance indicators such as service expansion, revenue collection, and non-revenue water. Performance monitoring systems are well established with institutions like economic regulation and supporting tools like ISO standards (ISO, n.d.), benchmarking (IBNET, n.d.), rating tools (Alegre et al., 2016), and the "utility turn-around" framework (Janson et al., 2018). In urban sanitation, these concepts have been lightly applied to utility sewerage but typically not to all types of urban sanitation services. Efforts to apply utility and urban service concepts to urban sanitation include the Urban Sanitation Fundamentals of Good Practice Note (Tayler and Parkinson, 2003), the Practitioner's Companion online Toolkit (MIT, 2001), the Sandec-UNITAR-WBI Sector Governance in Sanitation curriculum, the World Bank's city service delivery assessment (CSDA), and Water and Sanitation for the Urban Poor's Sector Functionality Framework (Sandec-UNITAR-WBI, 2008; Ross et al., 2016; Drabble et al., 2017). Unfortunately, all of these have seen limited adoption in practice.

The CWIS service framework attempts to close this gap. Based on existing literature, well-established utility service theory and practice, and SDGs, especially 6 and 11, it offers a simplified but coherent conceptual frame for public service delivery systems that mainstream low-income communities' needs, and a range of appropriate technologies, service models, and governance mechanisms. Figure 3 highlights the shift 


\begin{tabular}{|c|c|c|c|}
\hline & \multicolumn{3}{|c|}{ SERVICE OUTCOMES } \\
\hline & CONVENTIONAL APPROACH & FSM APPROACH & $\begin{array}{l}\text { CITYWIDE INCLUSIVE } \\
\text { SANITATION APPROACH }\end{array}$ \\
\hline 咅 & $\begin{array}{l}\text { Sewerage/treatment } \\
\text { investments for central } \\
\text { distritcts; Small } \\
\text { proportion of population } \\
\text {-often in non-poor } \\
\text { metro neighborhoods- } \\
\text { receive largest share of } \\
\text { public investment and } \\
\text { highest level of service } \\
\text { for the lowest household } \\
\text { payment resulting in de } \\
\text { facto regressive cross- } \\
\text { subsidies. }\end{array}$ & $\begin{array}{l}\text { Low income communities } \\
\text { dependent on projects, informal } \\
\text { sector, social enterrpises; } \\
\text { serving the poorest remains a } \\
\text { challenge external to core } \\
\text { governance efforts; Focus on } \\
\text { short term full-cost recovery } \\
\text { from households; Public } \\
\text { financing and subsidies often } \\
\text { seen as inappropriate or } \\
\text { unaffordable, especially for safe } \\
\text { containment. }\end{array}$ & $\begin{array}{l}\text { Public investments and } \\
\text { subsidies prioritize } \\
\text { reaching the poor and most } \\
\text { vulnerable; 俛es and } \\
\text { government support based } \\
\text { on cost of service, service } \\
\text { level, and ability to pay } \\
\text { across sewered and non- } \\
\text { sewered customer } \\
\text { segments; gender } \\
\text { intentionality explicit to } \\
\text { achieving outcomes and } \\
\text { proper execution of } \\
\text { functions. }\end{array}$ \\
\hline 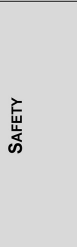 & $\begin{array}{l}\text { Small portion of human } \\
\text { waste is collected; } \\
\text { Treatment works have } \\
\text { limited / unreliable long- } \\
\text { term performance; } \\
\text { Poorest communities } \\
\text { receive least public } \\
\text { collection but face } \\
\text { greatest environmental } \\
\text { health risks / damage } \\
\text { from poor city services. }\end{array}$ & $\begin{array}{l}\text { Small pilots have limited reach, } \\
\text { variable and often unsustained } \\
\text { performance; Informal } \\
\text { providers provide services that } \\
\text { are limited, inefficient and } \\
\text { unsafe for city, households and } \\
\text { workers and is challenging to } \\
\text { improve. Interventions tend to } \\
\text { focus on collection and } \\
\text { treatment; unsafe containment } \\
\text { often lower priority. }\end{array}$ & $\begin{array}{l}\text { Safely managed sanitation } \\
\text { does not ignore safe } \\
\text { containment; Focus on fit- } \\
\text { for-purpose technology } \\
\text { choice with citywide, } \\
\text { systems lens, not specific } \\
\text { hardware approach. } \\
\text { Worker rights integrated } \\
\text { into definition of safety } \\
\text { requires inclusivity to } \\
\text { achieve city-level safety } \\
\text { outcomes. }\end{array}$ \\
\hline \multirow[t]{3}{*}{ 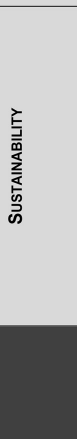 } & $\begin{array}{l}\text { O\&M costs, technical, } \\
\text { water and energy } \\
\text { requirements for } \\
\text { hardware acceptable for } \\
\text { public investments and } \\
\text { services (generally } \\
\text { sewerss tend to exceed } \\
\text { resources available or } \\
\text { allocated; Capital } \\
\text { maintenance deferred; } \\
\text { infrastructure } \\
\text { deteriorates/depreciates. } \\
\text { All other approaches are } \\
\text { relegated to private retail } \\
\text { markets. }\end{array}$ & $\begin{array}{l}\text { Projectized approaches not } \\
\text { integrated with broader public } \\
\text { management systems limit post- } \\
\text { project performance; Lack of } \\
\text { institutional clarity, and/or lack } \\
\text { of priority keeps SSM on the } \\
\text { 'fringes' of mainstream } \\
\text { planning and investments; FSM } \\
\text { 'add-ons' to core centralized } \\
\text { inffrastructure plans. }\end{array}$ & $\begin{array}{l}\text { - Investments, technologies, } \\
\text { pricing and other systems } \\
\text { features are designed and } \\
\text { implemented to be viable } \\
\text { in the context of financial, } \\
\text { water, energy, land, human } \\
\text { resource flows and } \\
\text { limitations; system } \\
\text { incentives are designed to } \\
\text { perpetuate and improve } \\
\text { service outcomes. }\end{array}$ \\
\hline & \multicolumn{3}{|c|}{ SYstem Functions } \\
\hline & CONVENTIONAL APPROACH & FSM APPROACH & $\begin{array}{l}\text { CITrWIDE INCLUSIVE } \\
\text { SANITATION APPROACH }\end{array}$ \\
\hline 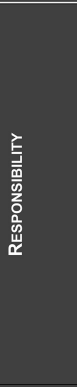 & $\begin{array}{l}\text { Authority/utility often } \\
\text { with legal or de facto } \\
\text { mandate only for } \\
\text { conventional sewered } \\
\text { area; authority not } \\
\text { expected to plan, invest } \\
\text { or serve full city or larger } \\
\text { urban-growth affected } \\
\text { area; On-site services } \\
\text { typically excluded from } \\
\text { mandate, not executed, or } \\
\text { mandate is fragmented to } \\
\text { multiple authoritities based } \\
\text { on hardware and } \\
\text { administrative } \\
\text { definitions, boundaries } \\
\text { not need or function. }\end{array}$ & $\begin{array}{l}\text { Lack of clear mandate and/or no } \\
\text { active authority responsible for } \\
\text { ensurings services in non- } \\
\text { sewered areas; informal and } \\
\text { formal private businesses } \\
\text { (primarily emptiers) operate } \\
\text { without recognition, regulation } \\
\text { or engagement, despite } \\
\text { providing the bulk of services; } \\
\text { NGO and social enterprise } \\
\text { interventions 'never fail, never } \\
\text { scale.' }\end{array}$ & $\begin{array}{l}\text { Responsible public } \\
\text { authority(ies) required to } \\
\text { fully take on mandate for } \\
\text { service outcomes for alll } \\
\text { Private sector participation } \\
\text { occurs within a clear } \\
\text { institutional framework } \\
\text { and with specific } \\
\text { engagement models (e.g. } \\
\text { service contracts, } \\
\text { agreements) and } \\
\text { regulations; Households, } \\
\text { private sector and informal } \\
\text { sector should benefit with } \\
\text { proper market structuring } \\
\text { and investmments. }\end{array}$ \\
\hline & $\begin{array}{l}\text { Regulators use nominal } \\
\text { Key Performance } \\
\text { Indicators (KPIs), for } \\
\text { sewereds systems only, if } \\
\text { at all; Missing data } \\
\text { collection systems } \\
\text { (especially for on-site } \\
\text { populations) limit } \\
\text { performance or tariff } \\
\text { accountability sovereign } \\
\text { loan guarantees weaken } \\
\text { incentives to desing and } \\
\text { invest for appropriate or } \\
\text { sustained outcomes. }\end{array}$ & $\begin{array}{l}\text { Weak or absent codes, local } \\
\text { regulations; Lack of monitoring } \\
\text { and enforcement in the absence } \\
\text { of engaged mandated service } \\
\text { authority; Often tense } \\
\text { relationships between private } \\
\text { operators and authorities, } \\
\text { limiting trust. }\end{array}$ & $\begin{array}{l}\text { Outcomes are monitored } \\
\text { and authorities held } \\
\text { accountable for KPI targets } \\
\text { using tools such as } \\
\text { economic regulation and } \\
\text { mix of positive and } \\
\text { negative incentives. } \\
\text { Understanding progress } \\
\text { and costs creates space, } \\
\text { even demand, for } \\
\text { improvements, innovative } \\
\text { technologies and smarter } \\
\text { business models. }\end{array}$ \\
\hline 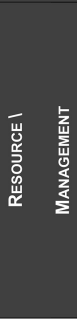 & $\begin{array}{l}\text { Central government and } \\
\text { concessional finance, } \\
\text { primarily for sewered } \\
\text { infrastructure, primarily } \\
\text { in largest cities; } \\
\text { Resources typically reach } \\
\text { first mile non-poor susers } \\
\text { first who tend to be able } \\
\text { but not required to pay } \\
\text { cost-recovery tariffs. } \\
\text { facto allocations not } \\
\text { based on effficiency, } \\
\text { inclusivitity performance } \\
\text { or sector priorities. }\end{array}$ & $\begin{array}{l}\text { FSM interventions often } \\
\text { projectized and short-term, } \\
\text { suffer from unreliable revenues; } \\
\text { Resource recovery is often } \\
\text { highlighted, but not scaled or } \\
\text { integrated into larger systems or } \\
\text { market signals/coordination }\end{array}$ & $\begin{array}{l}\text { Clear, transparent } \\
\text { financing frameworks } \\
\text { guidedata-driven decision } \\
\text { making on resource } \\
\text { allocations across } \\
\text { government levels; finance } \\
\text { can be tied to performance } \\
\text { against goals and long- } \\
\text { term plans }\end{array}$ \\
\hline
\end{tabular}

FIGURE 3 | Comparing CWIS to conventional and FSM approaches. 
from previous approaches to urban sanitation that were defined around hardware categories rather than service needs. "Conventional Approach" defined sewered sanitation as relevant for public investment and management, and all other technology approaches were managed outside of public service systems. The "FSM Approach" failed to course correct this by emphasizing its inherent advantage over sewers for reaching the poor without considering the context or need for broader planning and public service delivery systems.

This comparison illustrates some of the barriers to reaching sustainable development goals with hardware-focused interventions when those Goals are not integrated into mainstream planning, investments and institutional designs, and if interventions for low-income and on-site oriented populations remain relegated to pilot, "add-on" or phase two projects. The CWIS frame integrates FSM interventions into citywide service systems, improving likelihood and scale of safe, equitable and sustained service outcomes.

\section{MAKING IT WORK: TOWARD CWIS IN PRACTICE}

The CWIS framework and principles have and will continue to evolve as experience and practice grows. Since 2017, a growing number of public service authorities, policy makers, and development banks are aligning with the underlying imperatives of CWIS. Several global institutions are working to reframe their urban sanitation strategies and investments around public service system functions and outcomes, and to strengthen the focus on equity and inclusivity. The World Bank, Asian Development Bank, and the African Development Bank have all made substantial commitments to the adoption of CWIS within their investment portfolios (African Development Bank Group, 2018; Cheney, 2018; The World Bank, 2019). UNICEF has adopted CWIS as a key initiative within its new global framework for urban WASH (UNICEF, 2019a). Others are increasingly engaging.

While some national governments, for example the Government of Bangladesh (DPHE and ITN-BUET, 2019), as well as sub-national and city authorities have begun to consider how to integrate CWIS elements into their work, it is still a new concept and requires significant awareness-raising, advocacy and adaptation. To this end, regional organizations such as the Eastern and Southern African Water and Sanitation Regulators Association (ESAWAS) and the African Water Association (AFWA) have begun to frame their support to member regulators and utilities using the CWIS principles. Likewise, a growing number of capacity-building organizations, academic institutions, and other development partners are providing technical assistance and advocacy required to reorient the sector toward a public service delivery approach.

The emerging consensus and broad commitment to CWIS is promising, and essential if the principles are to influence sector priorities and practice. The Gates Foundation is hoping to amplify sector efforts by contributing to them in four ways: (1) demonstrating and documenting good practice, and creating space for learning; (2) building technical and human resource capacity; (3) supporting partners to enable policy and institutional reforms - including to establish or strengthen monitoring systems for outcomes at all levels required for CWIS principles to translate into meaningful progress toward the SDGs; and (4) catalyzing technology and product innovation responsive to the challenges authorities face in delivering inclusive, viable services particularly in the context of climate change, rapid urbanization, and limited finance. The Foundation's CWIS City Partnership Portfolio includes eight "learning laboratory" city partnerships across five countries $^{2}$ where city authorities are experimenting with how to operationalize CWIS principles in a diversity of contexts and are informing replication and institutionalization efforts at state and national levels. Partnerships with international financing institutions and their national government clients, as mentioned above, are intended to accelerate mainstreaming of CWIS principles within large-scale urban investments. Support for capacity building activities, tools and peer exchange is enabling sector professionals to become familiar with the alternative engineering, institutional and organizational approaches required to implement CWIS.

Arguably a critical and urgent gap relates to how the sector measures and informs urban service system changes. Robust public data systems are required for iterative planning, practice, and accountability. Systems must be compatible with, inform and be informed by sector efforts to measure and track the urban SDGs. This means institutionalizing coordinated measurement systems on at least three levels:

\section{City Level Data System for Planning and Improving Services}

Municipal and utility driven performance indicators and systems for monitoring progress allow authorities to plan and improve city-level systems based on actual performance against goals. This must include, for example, household-level data (disaggregated to inform how services meet needs of women and marginalized populations), better assessments of containment infrastructure, and tracking of services along the service chain, and a better understanding of the links between infrastructure and service gaps and the context-specific public health risks.

\section{National- and/or State-Level Data Collection Systems for Accountability and Resource Management}

Explicitly inclusive Key Performance Indicators and associated data systems are required to translate authorities' mandates into clear goals and incremental targets and to hold them accountable for making progressive improvements using transparent incentives and penalties. Data systems are essential for operationalizing national financing and accountability frameworks and reporting meaningfully against SDG commitments. Currently, nationallevel reports of safely managed sanitation are largely

\footnotetext{
${ }^{2}$ These include: Dakar, Senegal; Kampala, Uganda; Lusaka, Zambia; Khulna,
} Bangladesh and Narsapur, Warangal, Wai, and Tiruchirapalli in India. 
unavailable or remain high-level estimates (UNICEF, 2019b), and performance monitoring for sanitation services-particularly for on-site population segments-is rarely practiced.

\section{Project-Level Lending and Investment in Data Collection Systems for Learning and Financing Efficiency}

Scarce global finance for urban sanitation makes its efficient use an imperative. Consistent, CWIS-aligned project indicators for multinational, bilateral, and central government investments in urban sanitation are needed to improve design and implementation of new investments, to enable better understanding of planned and actual outcomes of investments, and to strengthen inherently weak feedback and accountability mechanisms associated with infrastructure financing. Investments need to prioritize establishing or strengthening authorities' data systems, rather than projectizing data collection to fill the gaps of missing public information management systems for discrete interventions.

\section{SOME UNANSWERED QUESTIONS \& IMPLICATIONS FOR POLICY \& PRACTICE}

Broad energy around still-early CWIS efforts indicates general support for the proposed concepts, but more importantly a clear consensus that the status quo must change. Reimagining sector goals and ways of working is a good first step. It is a far more complicated task to reshape them. At present, CWIS is a conceptual frame still largely unfamiliar to government stakeholders or sector professionals. Time will tell whether this frame can generate value for practitioners and service authorities, and whether its use can drive better service outcomes. At this stage, several important questions emerge:

- The CWIS public service approach to urban sanitation is new for most cities and countries. What does it take to institutionalize CWIS principles within national policies, regulatory frameworks, organizational arrangements? What financial and technical assistance is needed at national and city levels to support organizational change and transition from the status quo to CWIS implementation?

- What advocacy efforts are required to build an actionable understanding of the concepts underpinning the CWIS acronym? What advocacy is needed to drive the mainstreaming and improvement of FSM and inclusivity within CWIS - starting with establishing safe containment? How can local private and public innovations to improve CWIS outcomes be incentivized and integrated into systems and norms so they are sustained and scaled?

- What metrics and monitoring systems are needed to inform and monitor sector-, national-, and city-level progress? Global and regional SDG monitoring can be based on national estimates, but systems for monitoring city-level services, upon which national reports should be based, will be harder to normalize and implement.

- What do good incentives and investments look like when using CWIS principles? To what degree do the infrastructure to operational cost ratios change and what are the implications for existing financing tools? How should the sources and proportions of public, private and household financial contributions change to prioritize equity, safety and sustainability? How are capacity development and other real transition costs funded to ensure organizations like utilities achieve complex systemlevel transitions?

- What are the limitations of CWIS implementation given the limitations of existing urban sanitation technologies in the market? What do we need to learn in order to prioritize interventions that will optimize health and dignity benefits? What are the specific technology innovation opportunities that could stepwise improve inclusivity, safety or viability of service and business models in the context of weak or nascent sector governance and limited funds?

- What can we learn from reforms in other public service sectors that required deep change management, innovation and experimentation? What are realistic expectations in terms of the pace, scale and depth of change required to transition cities and countries toward entirely new approaches? How do we encourage experimentation, learning-by-doing, and acknowledgment of failure in the context of risk-aversion and strong incentives to continue with the status quo?

- How can a CWIS frame support integrated urban waste and water management? When is it necessary to consider integrated systems to advance sustainability and safety of service provision? What does the CWIS frame offer for drainage, solid waste management and other city service goals and investments?

These and other questions need to be considered in ways that inform practice, curriculum, policies, and tools if our pursuit of SDG 6, as well as SDGs 1, 3, and 11, is serious.

This paper outlines the evolution of CWIS and presents the CWIS service framework as an integrated systemschange approach for equitable, safe, and sustained urban sanitation service outcomes. It is a point of convergence, pulling together threads from the work and lessons of many. It is also a point of departure for all those committed to making progress in urban sanitation - government, utilities, service providers, private sector, NGOs, civil society, and funders. The impetus and momentum for CWIS rests on the notions that prevailing approaches to expand sanitation coverage are both inadequate and inappropriate for achieving urban sanitation SDGs, that inclusive urban sanitation requires a public service approach that prioritizes reaching the poor, and that making CWIS work in practice requires significant changes to how all sector professionals think, plan, and work. 


\section{AUTHOR CONTRIBUTIONS}

AS, JR, DP, and RS conceived of the idea, and outlined the brief. AS created the comparison table and $2 \times 3$ framework. JR wrote a first outline of the manuscript and detailed the introduction. AS and DP detailed in sections "Toward a New Framework: Defining Citywide Inclusive Sanitation," "Making it Work: Toward Cwis in Practice," and "Some Unanswered Questions \& Implications for Policy \& Practice." RS provided in-depth review and additional materials for sections "Making it Work: Toward Cwis in Practice"

\section{REFERENCES}

ADB (2018). Leading Factors of Success and Failure in Asian Development Bank Urban Sanitation Projects. Manila: Asian Development Bank.

African Development Bank Group (2018). African Development Bank to Invest Over US\$ 500 Million in New City Wide Inclusive Sanitation Projects with Support From Gates Foundation. Available at: https: //www.afdb.org/en/news-and-events/african-development-bank-to-investover-us-500-million-in-new-city-wide-inclusive-sanitation-projects- withsupport-from-gates-foundation- 18644 (accessed August 15, 2019).

Alegre, H., Baptista, J. M., Enrique, C. Jr., Francisco, C., Patricia, D., Wolfram, H., et al. (2016). Performance Indicators for Water Supply Services. London: IWA.

Aquaconsult (2018). Engaging with the Private Sector for Urban Onsite Sanitation Services: Lessons from Six Sub-Saharan African Cities. Seattle: Bill \& Melinda Gates Foundation.

Blackett, I., and Hawkins, P. (2017). FSM Innovation: Overview and Analysis. Seattle: Bill \& Melinda Gates Foundation.

Cheney, C. (2018). At the Reinvented Toilet Expo, New Commitments to Bring Innovation to Sanitation. Devex. Available at: https://www.devex.com/news/ at-the-reinvented-toilet-expo-new-commitments-to-bring-innovation-tosanitation-93787 (accessed August 15, 2019).

DPHE and ITN-BUET, (2019). Report of National Consultation Meeting on CityWide Inclusive Sanitation (CWIS). Dhaka: DPHE.

Drabble, S., Renouf, R., and Stokes, J. (2017). An Evaluative Framework for Urban WASH Sector Funtionality. London: WSUP.

Galli, G., Nothomb, C., and Baetings, E. (2014). Towards Systemic Change in Urban Sanitation. Hague: IRC.

Gambrill, M., Rosenboom, J. W., Evans, B., Moe, C., Perez, E., Trémolet, S., et al. (2016). Addressing the Urban Sanitation Crisis: Time for a Radical Shift. Available at: https://blogs.worldbank.org/water/addressing-urban-sanitationcrisis-time-radical-shift (accessed August 14, 2019).

IBNET (n.d.). IBNET: The International Benchmarking Network. Available at: https: //www.ib-net.org/ (accessed August 15, 2019).

ISO (n.d.). GOAL 6: Clean Water And Sanitation. Available at: https://www.iso.org/ sdg06.html (accessed August 15, 2019).

Janson, N., Piantini, S., and Gerard, G. (2018). Water Utility Turnaround Framework: A Guide for Improving Performance. Washington D.C: The World Bank.

Klein, M. (1996). Economic Regulation of Water Companies. Policy Research Working Paper 1649. Washington DC: The World Bank.

Komives, K. (1999). Designing Pro-Poor Water and Sewer Concessions: Early Lessons from Bolivia. Washington DC: The World Bank.

MIT (2001). Toolkit: A Practitioner's Companion. Available at: http://web.mit. edu/urbanupgrading/waterandsanitation/home.html (accessed November 19, 2019). and "Some Unanswered Questions \& Implications for Policy \& Practice." RB wrote the materials on monitoring systems. All authors contributed to manuscript revision, read and approved the submitted version.

\section{FUNDING}

This work was supported through employment of authors at the Bill \& Melinda Gates Foundation.

Ross, I., Scott, R., Mujica, A., White, Z., and Smith, M. (2016). Fecal Sludge Management: Diagmostics for Service Delivery in Urban Areas; Tools and Guidance. Washington DC: The World Bank.

Sandec-UNITAR-WBI (2008). Governance in Urban Sanitation Sector. Module 3: Institutional Aspects. Tunis: WBI.

Strande, L., and Ronteltap, M. (2014). Faecal Sludge Management: Systems Approach for Implementation and Operation. London: IWA.

Tayler, K., and Parkinson, J. (2003). Effective Strategic Planning for Urban Sanitation Services: Fundamentals of Good Practice. London: GHK International.

The Bill and Melinda Gates Foundation [BMGF] (2016). Emory University, Plan International, The University of Leeds, WaterAid, and the World Bank. Citywide Inclusive Sanitation: A Call to Action. 07 01. Available at: https://citywideinclusivesanitation.com/ (accessed August 12, 2019).

The World Bank Group (2017). A Thirst for Change: An IEG Evaluation of the World Bank Group's Support for Water Supply and Sanitation, with Focus on the Poor, FY2007-16. Washington D.C: The World Bank.

The World Bank (2019). Sanitation. Available at: https:/www.worldbank.org/en/ topic/sanitation\#2 (accessed August 2, 2019).

UNICEF (2019a). Global Framework for Urban Water, Sanitation and Hygiene. New York, NY: UNICEF. Available online at: https://www. unicef.org/media/63941/file/Global\%20Framework\%20for\%20Urban\% 20Water,\%20Sanitation\%20and\%20Hygiene.pdf (accessed February 20, 2020).

UNICEF (2019b). Progress on Household Drinking Water, Sanitation and Hygiene 2000-2017: Special Focus on Inequalities. WHO and UNICEF. New York, NY: UNICEF.

United Nations [UN] (2014). World Urbanization Prospects, the 2014 Revision. San Francisco, CA: United Nations.

UN-Water GLAAS (2017). Financing Universal Water, Sanitation and Hygiene Under the Sustainable Development Goals. Geneva: World Health Organization.

World Bank (2019). Open Data Platform - Urban Population Data. Available at: https://data.worldbank.org/ (accessed July 31, 2019).

Conflict of Interest: The authors declare that the research was conducted in the absence of any commercial or financial relationships that could be construed as a potential conflict of interest.

Copyright (C) 2020 Schrecongost, Pedi, Rosenboom, Shrestha and Ban. This is an open-access article distributed under the terms of the Creative Commons Attribution License (CC BY). The use, distribution or reproduction in other forums is permitted, provided the original author(s) and the copyright owner(s) are credited and that the original publication in this journal is cited, in accordance with accepted academic practice. No use, distribution or reproduction is permitted which does not comply with these terms. 